\title{
Seed and Seedling Ecology Research to Enhance Restoration Outcomes
}

\author{
Jeremy J. James, ${ }^{1}$ Chad S. Boyd, ${ }^{2}$ and Tony Svejcar ${ }^{3}$ \\ Authors are ${ }^{1}$ Director and Rangeland Extension Specialist, Sierra Foothills Research and Extension Center, University of California Agriculture and \\ Natural Resources, Browns Valley, CA 95918, USA; and ${ }^{2}$ Rangeland Ecologist and ${ }^{3}$ Research Leader, USDA-NRCS Eastern Oregon Agricultural \\ Research Center, Burns, OR 97720, USA.
}

Rangelands support almost one-third of the global population, store about one-half of the global terrestrial carbon, support $50 \%$ of the world's livestock, and contain over one-third of the global biodiversity hot spots (Millennium Ecosystem Assessment 2005). Rangelands, however, are one of the most susceptible biomes to land degradation and global climate change (Millennium Ecosystem Assessment 2005; Reynolds et al. 2007). Conservative estimates indicate $10-20 \%$ of rangeland worldwide are degraded with an additional 12 million ha of rangeland degraded each year (Millennium Ecosystem Assessment 2005).

The impacts of rangeland degradation on ecosystem sustainability as well as economic and political stability are widely recognized (UNCCD 2012). Globally, rangeland restoration is seen as key in mitigating these threats and an essential part of the pathway toward global sustainability. In line with this expectation, many countries spend more than $\$ 100$ million a year on efforts to restore rangeland systems. Despite the widely accepted importance of rangeland restoration and relatively large amounts of money invested in these activities, restoration success rates in these systems are overwhelmingly poor (Valladares and Gianoli 2007; Hardegree et al. 2011). As one recent example, the United States Department of Agriculture Conservation Effects Assessment Project found that even with application of the most current science, technology, and funding models, dryland restoration success rates are often less than 5\% (Sheley et al. 2011). Our current rangeland restoration science, policies, and practices are falling well short of the global need to combat the chronic and mounting degradation of these critical systems.

This special issue includes a broad examination of major biotic and abiotic processes that influence seed production and carryover as well as seed and seedling survival and establishment for desired and undesired plant species. These processbased, population-level lines of inquiry provide the foundation for understanding how to prevent degradation to rangeland systems and how to restore rangelands once they are degraded. Research over the past several decades has made significant contributions to this knowledge base. Yet these sustained advances in understanding seed ecology and seedling recruitment on rangelands have not translated into proportional advances in our ability to repair critical functions of these ecosystems following degradation. We acknowledge that knowledge sharing between science and management is not a

\footnotetext{
Correspondence: J. J. James, Sierra Foothills Research and Extension Center, University of California Agriculture and Natural Resources, 8279 Scott Forbes Rd, Browns Valley, CA 95918, USA. Email: jjjames@ucanr.edu
}

Manuscript received 13 February 2013; manuscript accepted 13 February 2013.

(c) 2013 The Society for Range Management simple process and that it involves challenging ecological and socioeconomic issues such as our ability to predict ecosystem response following disturbance and how restoration activities are funded, as well as the relative cost, benefits, and incentives for pursuing restoration activities (Suding and Hobbs 2009; Brunson and Tanaka 2011). As a way to frame this special issue we argue that increased understanding of seed and seedling ecology can overcome some of these restoration barriers by providing enhanced rangeland management and restoration decision-making frameworks.

Applied ecology fields, such as rangeland ecology, have made great strides in developing conceptual models of plant community dynamics and using these models to guide management and restoration decision making. While conceptual management models are broadly recognized as useful frameworks for organizing information and formulating general predictions of management effects on plant community change, there is a strong need to begin to understand, predict, and manage the processes and mechanisms driving transitions among plant community states. Seed and seedling ecology research, such as the research described in this special feature, provides the process-level information that will allow us to meet this need. Incorporating process-level information into conceptual management frameworks can increase model specificity, which can provide an enhanced ability to forecast management and restoration outcomes. Moreover, as models become more specific and quantitative they become increasingly more amendable to sensitivity analysis and identification of the process or groups of processes that provide the largest influence on state changes (Bashari et al. 2008; Norris 2012). This level of insight is needed if we are to foster high-impact collaborative research and management efforts and provide rankings for our most critical science and information needs.

Publication of this special feature of seed and seedling ecology provides an opportunity to reflect on the urgent need to combat rangeland degradation worldwide and consider how we might more strongly link our science and management frameworks over the next decade to meet this serious need. The processes of seed production, seed bank carryover, seedling establishment, and seedling persistence are at the heart of rangeland management and are fundamental to understanding how to repair and prevent degradation to these critical ecosystems. While our global rangeland management challenges are great and likely to further increase over the next several decades, there are large opportunities to link process-level work to ongoing efforts to develop conceptual management models. Such linkages may greatly accelerate our ability to maintain and restore healthy rangeland and provide a mechanism to foster the broad research-management partnerships needed to solve these pressing challenges. 


\section{LITERATURE CITED}

Bashari, H., C. Smith, and O. J. H. Bosch. 2008. Developing decision support tools for rangeland management by combining state and transition models and Bayesian belief networks. Agricultural Systems 99:23-34.

Brunson, M. W., And J. Tanaka. 2011. Economic and social impacts of wildfires and invasive plants in American deserts: lessons from the Great Basin. Rangeland Ecology \& Management 64:463-470.

Hardegree, S. P., T. A. Jones, B. A. Roundy, N. L. Shaw, and T. A. Monaco. 2011. Assessment of range planting as a conservation practice. In: D. D. Briske [ED.]. Conservation benefits of rangeland practices: assessment, recommendations, and knowledge gaps. Lawrence, KS, USA: Allen Press. p. 171-212.

Millennium Ecosystem Assessment. 2005. Ecosystems and human well-being: desertification synthesis. Washington, DC, USA: World Resources Institute. $26 \mathrm{p}$.

NorRIS, K. 2012. Biodiversity in the context of ecosystem services: the applied need for systems approaches. Philosophical Transactions of the Royal Society B: Biological Sciences 367:191-199.
Reynolds, J. F., D. M. Stafford Smith, E. F. Lambin, B. L. Turner, M. Mortimore, S. P. J. Batterbury, T. E. Downing, H. Dowlatabadi, R. J. Fernandez, J. E. Herrick, E. HuberSannwald, H. Jiang, R. Leemans, T. Lynam, F. T. Maestre, M. Ayarza, and B. Walker. 2007. Global desertification: building a science for dryland development. Science 316:847-851.

Sheley, R. L., J. J. James, M. J. Rinella, D. M. Blumenthal, and J. M. DiTomasso. 2011. A scientific assessment of invasive plant management on anticipated conservation benefits. In: D. D. Briske [ED.]. Conservation benefits of rangeland practices: assessment, recommendations, and knowledge gaps. Lawrence, KS, USA: Allen Press. p. 291-335.

Suding, K. N., AND R. J. HobBs. 2009. Threshold models in restoration and conservation: a developing framework. Trends in Ecology \& Evolution 24:271279.

[UNCCD] United Nations Convention to Combat Desertification. 2012. Zero net land degradation: a sustainable development goal for Rio+20, UNCCD Secretariat recommendations for policymakers. May. Bonn, Germany: UNCCD. 00 p.

Valladares, F., and E. Gianoli. 2007. How much ecology do we need to know to restore Mediterranean ecosystems? Restoration Ecology 15:363-368. 